\title{
Debates
}

\section{The Spectre of Social Democracy: A Symptomatic Reading of the Power Resources Approach ${ }^{1}$}

\author{
Jörg Nowak, University of Nottingham, United Kingdom
}

\begin{abstract}
The subject of historical cognition is the battling, oppressed class itself. In Marx it steps forward as the final enslaved and avenging class, which carries out the work of emancipation in the name of generations of downtrodden to its conclusion. This consciousness, which for a short time made itself felt in the 'Spartacus', was objectionable to social democracy from the very beginning. In the course of three decades it succeeded in almost completely erasing the name of Blanqui, whose distant thunder [Eryklang] had made the preceding century tremble. It contented itself with assigning the working-class the role of the savior of future generations. It thereby severed the sinews of its greatest power. Through this schooling the class forgot its hate as much as its spirit of sacrifice. For both nourish themselves on the picture of enslaved forebears, not on the ideal of the emancipated heirs (Walter Benjamin, 1974: Thesis XII).
\end{abstract}

Nothing will be done without class hatred: neither the elaboration of theory, nor practical organization. ... Only one-sidedness, in science and in struggle, opens the way simultaneously to the understanding of everything and to its destruction (Tronti, 1966: $14,84 \mathrm{f})$.

In 2014 and 2015 German airline pilots went on strike more than twelve times in the framework of the small union Vereinigung Cockpit, which exclusively organises pilots. The strike was aimed at keeping the low pension age of pilots (legitimated by the higher probability of heart attacks for people above 50 years of age) and against outsourcing to low-wage subsidiaries of German airline Lufthansa, the lead company in the German domestic market. The pilots used both their associational and structural power successfully since they have a prime position in blocking air transport. According to the power resources approach (PRA), this would be a showcase model on how to organise successful labour action. But the political context is significant here - that is, the exclusive solidarity of pilots that organised apart from the cabin crew, which has its own trade union UFO, and the quite high salaries of Lufthansa pilots which amount to 200000 Euros a year after twenty years in the job. I use this example to underline a theoretical critique of the PRA that follows an unaddressed and unacknowledged rational choice model anchored in the theoretical sources used for it. The PRA describes the resources available, but says nothing about the ends to which those resources could be used. The strategic actions of unions are not only

\footnotetext{
1 Thanks for valuable comments which helped to shape this article go to Rina Agarwala, Jenny Chan, Alexander Gallas and Ben Scully. Note, however, that I have written this article in my personal capacity; it does not represent the views of the Editorial Board as a whole.
} 
shaped by the resources they have access to, but also by their assessment of how those resources will allow them to achieve their broader political goals.

On the political level, this theoretical orientation comes with economism and a socialdemocratic approach that fails to address the problems of how state power and corporate power are intertwined, how the world market constrains social-democratic projects, and how popular power and appropriation of the economy could be accomplished. In other words, I claim that this approach does not allow an evaluation of the difficulties which came with earlier socialdemocratic projects both in Europe and in countries like South Africa and Brazil, but instead pretends to renew and repeat social-democratic strategies. The PRA is stuck on the terrain of social democracy, which is a decidedly European terrain. While social-democratic strategies fail in today's Europe with a different social reality, they had a much more limited success outside of Europe. The economism of pilots who ignore the situation of the much lower-paid flight attendants is an example of this neglect of reality.

The PRA has become one of the most influential approaches in the field of labour studies a subdiscipline that, generally speaking, tries to stay away from theoretical work in a quite desperate manner. I claim that the PRA is not even a theory, but rather consists of a few illdefined concepts with no sound theoretical basis. This would not be such a huge problem if the PRA would not have the characteristic to be profoundly depoliticising. Some of its proponents implicitly assume that it can guide the orientation of workers' and social movement struggles (see Schmalz et al., 2018). The question of whether a social movement or union has access to certain power resources and whether it uses them in an adequate way tends to hide the more decisive questions about the goals and strategies of working-class and popular movements. It is in the nature of the PRA that the answers to these questions are taken for granted, and thus questions about political goals remain omitted.

I argue that this deficit lies in the theoretical grammar that informs this approach, which is rarely spelled out and discussed. There are two key texts that figure as the sources for the PRA first, "Power Resources Approach vs. Action and Conflict: On Causal and Intentional Explanations in the Study of Power" by Walter Korpi (1985) and, second, "Working-Class Power, Capitalist-Class Interests, and Class Compromise" by Erik Olin Wright (2000). Korpi's text locates power resources in a game-theoretical setting. Actors act with rational intentions, and, depending on how they perceive their own power resources and those of others, they will modify their actions. If they perceive that their adversaries have an overwhelming advantage of power resources, then actors would not act at all - the classical "non-decision". The problem with this rational choice approach has been spelled out in many early critiques (Kerbo, 1982; Edwards, 1992): it ignores that mobilisations happen in certain conjunctures, often influenced by political-economic crises or economic upswings, and it cannot explain why people in extremely violent settings like dictatorships engage in social movements. Both the anti-apartheid movement and strikes in South Africa and the democracy and workers movements in Brazil were at a high point when Korpi published his text in the mid 1980s - and if we stay true to his rational choice approach there was no incentive at all for poor people in those authoritarian states to become engaged, and yet they did become engaged. Korpi's (1983) own reference point was the Swedish model of social democracy. He argued in other writings from the same period that unions in Sweden got so powerful that they did not have to go on strike any more and could engage in a political exchange with employers and government, reviving the well-known theory of the withering away of the strike, earlier employed by Karl Kautsky (1910) and by Arthur Ross and 
Paul Hartman (1960). ${ }^{2}$ According to Korpi, not to go on strike can be either a sign of extreme weakness or of extreme strength of unions.

While there are reasonable examples of strong unions negotiating comparably good results with a low level of strike days (the German unions are an example), Korpi's approach ignores the high number of wildcat strikes in post-war Sweden (Fulcher, 1973; Ingham, 1974). In addition, it completely ignores another basis of the Swedish social-democratic compromise - imperialism. ${ }^{3}$ The multinational companies based in Sweden deal with strong Swedish unions and pay high wages to their core workforce but act like all other multinational companies in the Global South with a high amount of precarious work. A few of the Swedish companies that have operated for decades on the basis of super-exploitation, either through arms-length subcontracting or through subsidiaries in the Global South, are H\&M, Alfa Laval, Atlas Copco, SKF and Sandvik.

So, paradoxically, the main basis of the PRA is the theory of Korpi, which shows that workplace and union struggles become superfluous once the working class becomes very strong or very weak. Korpi's (1983) notion of a democratic class struggle - exerting influence via elections and political parties - figures as a late version of Eduard Bernstein's idea of a peaceful and parliamentary transition to socialism, ${ }^{4}$ distinguished from industrial conflict ("undemocratic class struggle"), in which Korpi sees employers having overwhelming resources of power due to their ownership of the means of production. Korpi maintains that the results of power struggles between classes remain open-ended, and that there are varieties to the degree of subordination of the working class in different national states - and he uses both those ideas to distinguish his view from what he calls the "structural functionalist" Marxism of Louis Althusser and Nicos Poulantzas (Korpi, 1985). This is not by coincidence and we will come back to this point later. Decisive here is that despite Korpi's insistence to the contrary, he is in fact promoting a pretty deterministic approach that bluntly says that weak actors would not engage in resistance if they don't have a rational chance of attaining some gains. This goes against all evidence from 200 years of working-class history, which demonstrates that an understanding of dignity and customary rights is a central source of motivation for popular movements (Thompson, 1963), and not a rational calculation of chances - every successful revolt or popular struggle is matched by a hundred that failed.

2 "The basic method was to take a measure of strikes as the dependent variable and to explain it with measures of the political power of labour, such as the average vote for social democratic parties, and of the degree of centralization of union power ... One evident difficulty is that researchers use broadly similar sets of variables and test their theories on the same group of OECD countries. It is hard to avoid a feeling that the same numbers have been crunched in subtly different ways without a great deal of advance in understanding. The more influential contributions such as those of Korpi and Shalev and of Shorter and Tilly (1974), had the benefit of deriving from knowledge of particular countries, but some of the wider statistical exercises seem to have been happy with discovering correlations without asking what they say about the nature of industrial conflict in, say, Australia or Japan. ... the underlying story in some of the exemplar countries has also been questioned. ... Moreover several developments of the period the postwar period in Sweden, J.N.] indicate not a growing power of labour but a change in the strategies of employers and the state in regulating conflict" (Edwards, 1992: 366-7).

${ }^{3}$ John Smith (2016) demonstrates in detail how outsourcing of production to low-wage countries via foreign direct investment and arms-length manufacturing leads to super-exploitation of workers and value transfer to imperialist countries.

${ }^{4}$ Eduard Bernstein (1850-1932) was an influential politician of German social democracy who stood for the current of revisionism in the 1890s, which said farewell to the idea of the overthrow of the state and violent revolution. On the theoretical level this came with a substitution of materialism by NeoKantianism. 
The text that is most often cited as the source for the PRA is the one by Erik Olin Wright (2000). ${ }^{5}$ This is another paradox since Wright's text does not extensively elaborate on power resources, but only refers to them briefly on one page while the other forty pages of his text dwell on a theory of class compromise. This theory refers to the work of Antonio Gramsci and Adam Przeworski, claiming that the growth of working-class power would, beyond a certain threshold, be beneficial to capital, due to a feedback effect of higher working-class purchasing power on commodity sales and profits of capitalists (basically the Keynesian framework, as Wright himself underlines). Korpi's work is a major reference for Wright, too, and it is pretty much in the vein of Korpi's perspective that the Swedish model and the German model of codetermination are the role models promoted by Wright. (Ironically, the text was published during a time when the German model had already produced an enormous wage discrepancy within the working class, the largest in the Eurozone, and often along ethnic lines.) Curiously, Wright does not delve into the reasons why the Swedish model became obsolete (although he does mention its demise). As in Korpi's account, political economy at large and imperialist exploitation of workers in poor countries do not enter into the equation, and we are served with an abstract model on how to work towards more equality via an institutional social-democratic strategy.

Schmalz et al. (2018), in their Introduction to a Special Issue of the Global Labour Journal, largely adopt the model of Korpi and Wright, and add a few more power resources like bargaining, symbolic, societal, logistical and institutional power. They argue that the different resources cannot be added in a mathematical fashion, but that they converge in specific contexts, which then requires "specific combinations which are crucial for unions' assertiveness" (Schmalz et al., 2018: 115). They claim that "the main objective of the PRA is to analyse the spaces of action of trade union and employees under given circumstances" (Schmalz et al., 2018: 116). Strategic choice of social movement actors would then imply the conscious decision of which power resources will be mobilised and/or developed. The authors grant some flexibility and also include riots and violent struggles by workers as social movement activities that can be included in the broad spectrum of resource mobilisation. But does that deepen or broaden an understanding of social conflicts and subaltern strategies?

The basic argument of resource mobilisation theory in social movement studies (also mentioned as a source of the approach by Schmalz et al.) was that increasing poverty and frustration in the population are not the main drivers for upheaval and mobilisation - a critique of the immiseration theory and much in line with Korpi's claims. But this is against much historical evidence and was criticised in an influential article of Harold Kerbo (1982). Kerbo claims that the resource mobilisation theory would only be adequate if applied to so-called "movements of affluence" that pop up in situations of growth and relative social security, and he distinguishes those from "movements of crisis". He also warns against a too formalistic definition of resources, for example when he points out that for unemployed people the resource of time increases enormously (an idea that does not enter into the PRA). Kerbo's approach was later expanded by other scholars with the identification of cycles of mobilisation and cycles of

\footnotetext{
5 This is apart from Beverly Silver's (2003) book Forres of Labour; Silver declares that she borrows the concepts of structural and associational power from Wright, and they do not form the main basis of her model of analysis. Her approach relies on the concepts of product cycles, various fixes (spatial fix, financial fix, product fix), the impact of wars and the hegemony of superpowers, the distinction of defensive and offensive workers' struggles and the notion of power resources. Thus, for her approach, the notion of power resources is rather one among others and not the central concept. See Nowak, Birke and Dutta (2018) for an elaboration on this.
} 
contention (Tarrow, 1998), acknowledging that the resource mobilisation approach cannot properly explain when and why mobilisation occurs, given that mobilisation is bound up with larger economic and social cycles.

Schmalz et al. and the Jena approach to power resources in general never address the gametheoretical and rational choice notions that come with the PRA, but go beyond them implicitly. They assume that unions often act below their potential capacities (thus they do not act "rational") because of a lack of knowledge about their resources. The PRA then would serve to hint to unions about the existence of those resources and how to activate them - that is, to uncover strategic options, so redeeming the "lack of rationality". Thus, political questions potential decisions to embark on a confrontative or accommodative, a mobilising or institutionalist strategy - are boiled down to a question of the adequate use of resources. It is here that the rational choice legacy of the PRA also affects the newer variant of Schmalz et al.

A sympathetic reading of Schmalz et al. and the Jena approach could respond that the idea behind the PRA is to change the political approach of unions through pointing at those resources. But this assumes implicitly that the corporatist integration of many trade unions is not accompanied by political and ideological convictions of union officials. As in the classical Hegelian Marxist model of Georg Lukacs (1923) - based on the notion that it is mainly the consciousness of actors that has to be "corrected" - it assumes that once a light is brought into the darkness of existing or potential power resources, trade unions would change their political orientation. While the sympathetic reader might respond that this is a strategy of slow processual change of unions' orientations, such a strategy remains bound to never openly claim a goal that differs from corporatist trade unionism. The context and content of corporatist trade unionism has changed decidedly in the past forty years since it does not just come with selective-interest politics as it did in the 1970s and 1980s in Europe, but has been structurally aligned with neoliberal concession bargaining since the 1990s, both in Europe and in emerging economies (Knox, 2016). Unions may in fact see those resources anyway but choose not to use them since this is not in line with their goals - that is, it does not match their political approach since they are already included in a completely different strategic option and have no incentive to change it (see the critique by Gallas in this issue). The crucial question at this point is whether the strategic dimension of situations of weakness, and how to overcome this weakness, can be grasped with the PRA. Any strategic debate would first have to name the goal of that strategy. ${ }^{6}$

In most debates of the PRA this goal is implicitly assumed as a given: unions should be able to successfully lead collective negotiations, and they should be accountable to their members. But to focus on these institutional questions is quite a narrow view: The larger political economy and the relations of property, market relations, political power and the state will constrain any profound social change if these are not addressed and tackled, which lies outside the perspective of PRA approaches. ${ }^{7}$ Moreover, the limitations of economistic trade unionism, however democratically organised internally, have been debated at length (Esser, 1982; Mueller-Jentsch, 1985; Webster, 1987; Hyman, 1989), and the debates on how to overcome those limits have fallen into oblivion it seems.

\footnotetext{
${ }^{6}$ One explicitly stated goal across a number of PRA approaches is the "revitalisation of trade unions". It is the metaphor of the awakening of a dead body that should serve as a warning sign towards the zombie nature of reanimated social democracy.

7 The concept of the institutional power resource might have been designed in order to remedy this problem. Like the other power resources, it remains a descriptive notion and does not address the problem of how structural conditions in capitalism will neutralise limited approaches to implement changes.
} 
It is exactly due to this non-debate of larger political strategies that the PRA remains wedded to a social-democratic framework - it does not offer concepts to criticise social democracy, which is problematic as long as social democracy remains the dominant ideology in the labour movement. That this framework is rarely spelled out explicitly but pervades all major variants of this approach effectively strengthens its persistence - the more an ideology is invisible and seemingly natural, the stronger it is.

Any more far-reaching strategy has to ask questions completely different from those that can be asked with the PRA. How can one build popular power that can appropriate the economy and regain control of the means of production in a world of globally connected production networks? How do social movements deal with the state and its repressive, ideological and administrative apparatuses? How can they weaken the power of those apparatuses and/or make them more accountable? How can the relationship between popular power and its representation in political organs be made permanent and accountable, different from prevailing socialdemocratic authoritarianism from the South African union federation COSATU (Congress of South African Trade Unions) to the Brazilian union federation CUT (Central Única dos Trabalhadores), and different from the authoritarian legacy of one-party dictatorships? I claim that these are urgent and decisive political questions, and that the PRA is rather fostering their disappearance while fuelling illusions about the viability of a new class compromise à la post-war imperialist social democracy. The various pink-wave governments in Latin America and their legacies show that any neglect of those questions will lead to a resurgence of inequality and authoritarianism - either within the formally socialist pink-tide governments or against them as a right-wing backlash.

Of course, popular power will need resources in the broadest sense of the term, but this has been understood and practised by popular movements all along. It will not be the clever analysis of the availability of power resources and their specific combination in a specific situation that will contribute to a new wave of subaltern revolts. What is missing today is rather a role model of popular socialist revolution that provides a convincing response to the unresolved questions raised above. If consensus can be reached on such a model, popular movements will also know how to create the resources for it. The problems that left and popular movements face today are of a profound political nature. It is thus not by accident that Korpi focuses on Althusser and Poulantzas with his criticism of contemporary Marxism. Both have at least tried to provide answers to the above questions, however insufficient they were - Althusser (1978: 75) with his insistence that a revolutionary organisation has to remain both outside the bourgeois and the proletarian state in order not to get enmeshed with the state as an instrument of class power, and Poulantzas (1978) with his option of a radical transformation of state power via a simultaneous double movement of an expansion of popular organisations that are formally outside of the state as well as the build-up of progressive centres within the state apparatuses. ${ }^{8}$

If the nature of the bourgeois state and the enormous difficulty of replacing it with an accountable and non-authoritarian project of popular power is not taken into account, any "strategic choice" will remain within very narrow confines. The same goes for the popular reappropriation of the economic process which is inevitably bound up with the state, but also with the question of experts, the division into managers and executors, the unequal distribution of competences and therefore with hierarchies within the working class.

\footnotetext{
${ }^{8}$ See Nowak (2017) for an elaboration of those problems.
} 


\section{REFERENCES}

Althusser, Louis (1978) Zu einigen Voraussetzungen der Staatsfrage in der marxistischen Theorie. Interview with Rossana Rossanda. In Die Krise des Marxismus, by Louis Althusser. Hamburg: VSA.

Benjamin, Walter (1974) Über den Begriff der Geschichte. Gesammelten Schriften I:2. Frankfurt am Main: Suhrkamp. http://members.efn.org/ dredmond/ThesesonHistory.html (accessed 25 September 2018).

Edwards, P.K. (1992) Industrial Conflict: Themes and Issues in Recent Research. British Journal of Industrial Relations, 30(3): 361-404.

Esser, Josef (1982) Gewerkschaften in der Krise. Frankfurt am Main: Suhrkamp.

Fulcher, James (1973) Class Conflict in Sweden. Sociology, 7(1): 49-70.

Hyman, Richard (1989) The Political Economy of Industrial Relations. Theory and Practice in a Cold Climate. Basingstoke: Macmillan.

Ingham, Geoffrey (1974) Strikes and Industrial Conflict. Britain and Scandinavia. London: Macmillan.

Kautsky, Karl (1910/1972) Eine neue Strategie. In Die Massenstreikdebatte, edited by Antonia Grunenberg. Frankfurt am Main: Europaeische Verlagsanstalt.

Kerbo, Harold R. (1982) Movements of 'Crisis' and Movements of 'Affluence'. A Critique of Deprivation and Resource Mobilization Theories. Journal of Conflict Resolution, 26(4): 645-663.

Korpi, Walter (1983) The Democratic Class Struggle. London: Routledge \& Kegan Paul.

Korpi, Walter (1985) Power Resources Approach vs. Action and Conflict: On Causal and Intentional Explanations in the Study of Power. Sociological Theory, 3(2): 31-45.

Knox, Robert (2016) Law, Neoliberalism and the Constitution of Political Subjectivity: The Case of Organised Labour. In Neoliberal Legality: Understanding the Role of Law in the Neoliberal Project, edited by H. Brabazon. Oxford: Routledge.

Lukacs, Georg (1923/2000). History and Class Consciousness. Studies in Marxist Dialectics. Cambridge, MA: The MIT Press.

Müller-Jentsch, Walther (1985) Trade Unions as Intermediary Organizations. Economic and Industrial Democracy, 6: 3-33.

Nowak, Jörg (2017) Louis Althusser's Critique of the Communist Party and the Question of the Postrevolutionary State. Rethinking Marxism, 29(2): 234-255.

Nowak, Jörg, Peter Birke and Madhumita Dutta (2018) Introduction. The New Upsurge of Strikes Tendencies, Challenges and Limits. In Workers' Movements and Strikes in the Twenty-First Century, edited by J. Nowak, P. Birke and M. Dutta. London: Rowman \& Littlefield.

Poulantzas, Nicos (1978) State, Power, Socialism. London: New Left Books.

Ross, Arthur M. and Paul T. Hartman (1960) Changing Patterns of Industrial Conflict. New York: John Wiley.

Schmalz, Stefan, Carmen Ludwig and Edward Webster (2018) The Power Resources Approach: Developments and Challenges. Global Labour Journal, 9(2): 113-134.

Silver, Beverly (2003) Forces of Labour. Workers' Movements and Globalization since 1870. Cambridge: Cambridge University Press.

Smith, John (2016) Imperialism in the Twenty-first Century. New York: Monthly Review Books.

Tarrow, Sydney (1998) Power in Movement: Social Movements and Contentious Politics, Cambridge: Cambridge University Press.

Thompson, Edward P. (1963) The Making of the English Working Class. London: Victor Gollancz.

Tronti, Mario (1966) Operai e Capitale. Torino: Einaudi.

Webster, Edward (1987) The Rise of Social Movement Unionism: The Two Faces of the Black Trade Union Movement in South Africa. In State, Resistance and Change in South Africa, edited by Philip Frankel, Noam Pines and Mark Swilling. London: Croom Helm.

Wright, Erik Olin (2000) Working-Class Power, Capitalist-Class Interests, and Class Compromise. American Journal of Sociology, 105(4): 957-1002. 


\section{BIOGRAPHICAL NOTE}

Jörg Nowak is a Marie Sklodowska-Curie Researcher at the University of Nottingham, United Kingdom. He works on labour conflicts in emerging economies, global infrastructure investment, state theory and Althusserian Marxism [Email: joerg.nowak@gmx.de]

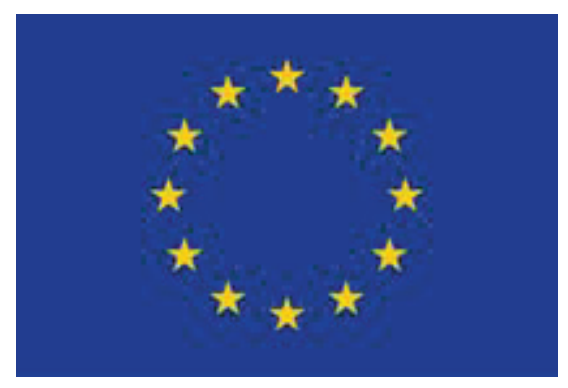

This project has received funding from the European Union's Horizon 2020 research and innovation programme under grant agreement No 74634. 